UDK 37(091)(477)(092):631(477)(092)

DOI 10.24919/2519-058x.0.184407

\title{
Viktor VERHUNOV
}

PhD hab. (Agricultural Sciences), Professor, Academician of National Academy of Agricultural Sciences (NAAS), specialty "History and Archeology», Director of the National Scientific Agricultural Library of NAAS, 10 Heroes Defense Street, Kyiv, Ukraine, postal code03127(dnsgb_uaan@ukr.net)

ORCID: http://orcid.org/ 0000-0002-5476-4845

Researcher ID: H-1636-2018

\section{Віктор ВЕРГУНОВ}

доктор сільськогосподарських наук, професор, академік Наџіональної академії сільськогосподарських наук (НАAН) зі спеціальності "Історія та археологія», директор Національної наукової сільськогосподарської бібліотеки НААН, вул. Героїв Оборони, 10, Київ, Україна, індекс03127(dnsgb_uаan@ukr.net)

Бібліографічний опис статті: Verhunov, V. (2019). Scientific organizational and pedagogical activity of the corresponding member of the USSR Academy of Sciences M. O. Tyulenyev (1889 - 1969): unknown and forgotten pages of life and creativity. Skhidnoievropeiskyi istorychnyi visnyk [East European Historical Bulletin], scientific conference proceedings, 38-52. doi: 10.24919/2519-058x.0.184407

\section{SCIENTIFIC ORGANIZATIONAL AND PEDAGOGICAL ACTIVITY OF THE CORRESPONDING MEMBER OF THE USSR ACADEMY OF SCIENCES M. O. TYULENYEV (1889 - 1969): UNKNOWN AND FORGOTTEN PAGES OF LIFE AND CREATIVITY}

\begin{abstract}
The purpose of the article is to highlight the creative achievements in the field of the drainage land reclamation in Ukraine of a prominent scientist, corresponding member of the Academy of Sciences of the Ukrainian SSR M. O. Tyulenyeva. The research methodology is based on the general scientific principles of the historical accuracy, objectivity, systematicity, complexity and scientific nature. M. O. Tyulenyev's life and achievements in the development of domestic reclamation science have been reconstructed, using the method of the historical and scientific analysis with the involvement of the previously inaccessible documents. The author used the general scientific, interdisciplinary and special historical methods, as well as a diverse source base, based on the archival documents. The scientific novelty of the article - for the first time it has been determined that, thanks to the development and practical recommendations of M. O. Tyulenyev, first of all, in the 1920-ies-1930-ies of the previous century, there took place an organizational formation of the scientific support system for the drainage reclamation in the Ukrainian SSR, its preservation during the German occupation of $1941-1943$ and its rise in the 50-ies-60-ies of the XXth century. The Conclusions. It has been proved that the scientist outlined the basic technological elements that allow a rational use of 3.3 million hectares of dried soils from more than 5 million reclamation fund of Ukraine. Their full and systematic introduction on the background of a primary tillage, a systematic use of fertilizers, the implementation of rational crop rotations and bilateral regulation of the water-air regime will allow to preserve the potential fertility of the drained lands and prevent their degradation. It has been illustrated that, on this basis, the growth and development of, first of all, a public animal breeding could occur for the needs of the country. M. O. Tyulenyev's scientific researches remain a «road map» for posterity to this day. It is not
\end{abstract}


by chance that the Ukrainian Parliament adopted the act to celebrate the 130th anniversary of the birth of M. O Tyulenyev in 2019 at the state level. The scientist did much in the name of the future and especially in the aspects of the theory, methodology and practice of an agricultural land reclamation.

Key words: Mykola A. Tyulenyev, drainage land reclamation, Ukrainian Research Institute of Hydrotechnics and Land Reclamation, Rudnya-Radovel swamp experiment station, Panfilska swamp experiment station, Institute of Plant Physiology and Agrochemistry, of Ukrainian Academy of Sciences, swamp culture.

\title{
НАУКОВО-ОРГАНІЗАЦІЙНА ТА ПЕДАГОГІЧНА ДІЯЛЬНІСТЬ ЧЛЕНА-КОРЕСПОНДЕНТА АН УРСР М.О. ТЮЛЕНСВА (1889 - 1969): НЕВІДОМІ ТА ЗАБУТІ СТОРІНКИ ЖИТТЯ ТА ТВОРЧОСТІ
}

\begin{abstract}
Анотація. Метою статті є висвітлення творчих здобутків на ниві осушувальних меліораиій в Україні видатного вченого, члена-кореспондента АН УРСР М. О. Тюленєва. Методологія досліджсення трунтується на загальнонаукових приниипах історичної достовірності, об 'єктивності, системності, комплексності та науковості. Методом історико-наукового аналізу із залученням раніше недоступних документів реконструйовано життя $i$ звитяги М. О. Тюленєва, його внесок у розвиток вітчизняної меліоративної науки. Автор використав загальнонаукові, міждисииплінарні та спеціальні історичні методи, а також різнопланову джерельну базу, основу якої становлять архівні документи. Наукова новизна: вперше встановлено, щуо завдячуючи розробкам, а також практичним рекомендачіям М. О. Тюленєва, саме у 20-30-х рр. минулого століття відбулось організаційне становлення системи наукового забезпечення осушувальних меліорачій в УСРР, його збереження під час німецької окупації 1941 - 1943 рр. та піднесення у 50-х - 60-х рр. ХХ ст. Висновки. Доведено, що вчений накреслив основні технологічні елементи, які уможливлюють рачіональне використання 3,3 млн га осушених трунтів із більш як 5 млн меліоративного фонду України. Їх повночінне і системне запровадження на фоні первинного обробітку трунту, системного внесення добрив, застосування раціональних сівозмін та двостороннього регулювання водно-повітряного режиму допоможе зберегти потенційну родючість осушуваних земель та запобігти їх деградаџіï. Показано, щзо на ичій основі могли відбутися зростання і розвиток насамперед громадського тваринництва для потреб країни. Наукові пошуки М. О. Тюленєва залишаються дорожньою картою для нащадків до сьогодення. Не випадково за зроблене в ім'я майбутнього, а особливо в питаннях теорії, методологї̈ та практики агромеліораційної дослідної справи, украӥнський парламент прийняв рішення про святкування 130-річчя від дня народження М. О. Тюленєва у 2019 р. на державному рівні.

Ключові слова: Микола Олександрович Тюленєв, осушувальні меліорачії, Украӥнський науково-дослідний інститут гідротехніки і меліоращиї, Рудня-Радовельська болотна дослідна станиія, Панфильська болотна дослідна станиія, Інститут фізіології рослин і агрохімії АН УРСР, культура боліт.
\end{abstract}

The Problem Statement. On December 18, 2018, Verkhovna Rada of Ukraine adopted its resolution on the state-level celebrations in 2019 (Decree, 2018). In accordance with Paragraph 1, it is recommended to celebrate solemnly 43 significant events, 96 - the jubilee celebrations of the outstanding personalities, 3 - Memory Days and 2 - the famous events of world history. Among them there are the dates, concerning the history of existence in Ukraine of the youngest component of the modern nature science and culture of the nation, namely, the experimental study. It is about the 130th anniversary of M. O. Tyulenyev, the corresponding member of the Academy of Sciences of the Ukrainian Soviet Socialist Republic and the 90th anniversary of the Research Institute of Agricultural Reclamation foundation (nowadays the Institute of Water Supply Issues and Reclamation of the NAAS). Both events are, to some extent, complementary, as M. O. Tyulenyev is directly involved in the emergence, in accordance with the decision of the RNC of the Ukrainian SSR, on December 23, 1929, of 
the current world-renowned branch scientific center in Ukraine on water supply problems and land reclamation. He also contributed to the deployment of his activities during the 1930-ies and 1960-ies, especially the issues on the theory and practice of the drainage land reclamation in the USR / USSR. His experience in this field was included in the «golden fund» of not only Ukrainian but also the world science (Palij, \& Khramov, 2018, p. 380).

The Analysis of Recent Researches and Publications. Some information on M. O. Tyulenyev is contained in the biographical editions references of the NAS of Ukraine (Palij, \& Khramov, 2018, p. 380), NAAS (Gimbarzhevs`ky`j, \& Kalanty`renko, 2003, pp. 316-318), the monographs, dedicated to the 75th Anniversary of the Institute of Hydrotechnics and Reclamation (Kovalenko, 2005, pp. 150). The article about the scientist was published in the Ukrainian Soviet Encyclopedia (Kalanty`renko, 1984, p. 41). Practically, other problematic publications, dedicated to M. O. Tyulenyev, are based on this biographical information (Bachkala, 2006; Dovghoruk, 2018). The preparation for the anniversary celebrations at the state level caused the expansion of the archival searches, which allowed the introduction series of the new documents, concerning his activities, for example, in «Ukrtorf» and the AgNCU (Agricultural National Committee of Ukraine) and his activity during the years of the Soviet-German war. In addition, the analysis of the scholarly work (the articles, the brochures, the abstracts, the reports, the speeches at conferences), including even the unknown or forgotten works, allowed us to fill with the new knowledge of the scientist and, most importantly, to expand the modern understanding of M. O. Tyulenyev's place and the role in the history of a systemic scientific organization research on the swamp culture not only in Ukraine but also in the Republic of Belarus.

The purpose of the article is to reveal the creative achievements in the field of the drainage land reclamation in Ukraine of the prominent scientist, a corresponding member of the Academy of Sciences of the Ukrainian SSR M. O. Tyulenyev, based on the use of the historical and scientific analysis method and the use of previously unavailable documents.

The Statement of the Basic Material. M. O. Tyulenev was born on April 5, 1889, in the village of Ivanivka Verkhnyodniprovskyi Povit of Katerynoslav Province (nowadays Dnipropetrovsk Region) according to some documents (Central State Archive of the Supreme Power and Administration of Ukraine, f. 27, d. 17, c. 4155, p. 6) in the family of an employee; according to other documents - he was born after April, 21 in the village of Hannivka. His father served in the Alexandrivske County Zemstvo (Kherson province) as a secretary of the administration with the title of a hereditary citizen (CSASPAU, f. 27, d. 17, c. 4155, p. 18). At first, his father died, who left his wife and children (the brother Constantine) a four-room house in Alexandria. M. O. Tyulenev's mother sold it almost immediately. Until her death in 1896, she was engaged in the home-schooling and literacy education. Unfortunately, it is unknown where M. O. Tyulenyev after «... the loss of his parents at the age of 7 years ...» (CSASPAU, f. 27, d. 17, c. 4155, p. 6) got a primary education, but it proved to be worthy of admission to the gymnasium. Perhaps, the most acceptable territorially gymnasium in Poltava was chosen for Mykola. At the entrance exams he illustrated the brilliant knowledge of all subjects, including the knowledge of German. According to some sources, M. O. Tyulenyev received his secondary education at one of the best gymnasiums in Tsarist Russia - the first Poltava Classical Men's Emperor Alexander I the Blessed (now - Poltava Specialized School No. 3), which had its history since 1808 and had the so-called boarding house in its structure for 40 pupils (the orphan class) for the impoverished nobles (Archive of the Ukrainian Research Institute of Hydrotechnics and Melioration, f. 5144, d. 2, c. 102, p. 30). According 
to other sources, in 1900 he studied in O. O. Bayer Open Poltava Commercial School, which was transformed into a trade and industrial school in 1924, which was located in Kharkiv in 1927 (CSASPAU, f. 27, d. 17, c. 4155, p. 18). At the age of 13, M. O. Tyulenyev began to pay for his education by conducting private lessons, and from the age of 14 he paid for his further education by tutoring (Archive of the Academy of Sciences of the USSR, f. 251, d. 567 , c. 34 , p. 16$)$.

At the beginning of his stay in Poltava, and because of his desire, M. O. Tyulenyev went to a classical gymnasium, and after his relatives lost the opportunity to pay for his education, he went to a commercial school. At least, he entered the university as «... the son of a merchant ...» (State Archive of Kyiv, f.18, d. 1, c. 757, p. 110). Other entry becomes clear. This entry was made later in the «Personal Recording Personnel Sheet», that M. O. Tyulenyev entered KPI «... by competition...» (AURIHM, f. 5144, d. 2, c. 102, p. 58).

Studying at the gymnasium for the first time he learned about the peatland and swamp fund of the region, using the expositions of Botany auditorium and Mineralogy auditorium, as well as the expositions of the Natural History Museum of Poltava Provincial Zemstvo (nowadays - Vasyl Krychevskyi Poltava Local History Museum). From 08.1907 till 01.01.1911 he studied at the agricultural department of Kyiv Polytechnic Institute of Emperor Alexander II (nowadays - National University of Bioresources and Environmental Management of Ukraine) (AAS, f. 251, d. 567, c. 34, p. 5). Already from the first year of studying he joined the revolutionary movement and took part in the protests, provoked by the new «Regulations on Higher Education» of June 11, 1907, which effectively eliminated all the main paragraphs on autonomy of the previously adopted regulations on August 27, 1905. The regulations already led to the closure of the university for a certain period. The sphere of scientific and natural interests was formed under the influence of the lectures and practical classes, conducted by a group of outstanding scientists and educators of that time, namely professors: P. R. Slyoznika, V. H. Bazhaeva, K. H. Schindler, D. V. Klyucharova, F. I. Levchenko, and etc.

On the recommendation of P. R. Slyoznika, he brushed up the gained knowledge in practice, working in the summers of 1909 and 1910 under the direction of the future academician VASHNIL, and at that time the director of Kharkiv research field - B. M. Rozhestvenskyi (1874 - 1943), making the collective experiments with the mineral fertilizers use under winter wheat and studying their aftereffects in Katerynoslav and Kharkiv provinces (AURIHM, f. 5144, d. 2, c. 10234, p. 30). At the beginning of 1910 he married Maria Ivanivna Maltseva (born on October 28, 1877) for the first time. (CSASPAU, f. 331, d. 2, c. 37, p. 30). A little later, namely on December 13, 1910, his only daughter Zoya was born (CSASPAU, f. 27, d. 17 , c. 4155 , p. 6$)$.

An orphan life, a constant overcoming of urgent problems exacerbated the tuberculosis disease to such a form that Verkhnodniprovsk district zemstvo for a military presence (something like the present regional military commissariats) gave him a corresponding certificate №3492 from 17.07.1911 with the conclusion «... not capable at all...» (CSASPAU, f. 27 , d. 17, c. 4155 , p. 1). In 1915, at the request of the Department of Agriculture № 33172, M. O. Tyulenyev's inability was again confirmed to be involved in a military service and even in the rear. On January 13, 1921, the Military Committee of Kyiv issued M. O. Tyulenyev the «White Ticket», which was stolen later (CSASPAU, f. 27, d. 17, c. 4155, p. 10).

After graduating from the university and passing the exam on May 31, 1911, he received the diploma No. 4189 of June 11, 1911 (CSASPAU, f. 27, d. 17, c. 4155, p. 1) the first category 
and the right «... the rank of the Xth class ... «, the so-called Peter's rank plate. His specialty is "a plant technician" or "a land reclamation agronomist". As one of the best graduates. From October 15, 1911 to January 1912 - a trainee of the Department of Agriculture of the Main Department of Agriculture and Land Management, as well as a specialist in agrochemicals in the established by the resolution of Minsk Provincial Committee on Agriculture on February 22, 1910 (Voron, 2016, p. 65) the first in the Russian Empire swamp experimental station Minsk swamp experimental station (nowadays - the Republican Scientific Subsidiary Unitary Enterprise «Institute of Reclamation» of the Scientific and Practical Center of the National Academy of Sciences of Belarus for Agriculture). The station began its functioning in July 1911 under the guidance of Doctor in Botany - O. F. Flerov. Minsk Provincial Administration assigned ten major tasks concerning the study of the peat and marsh fund of the region, which was confirmed by the Department of Agriculture, allocating 8250 rubles for the experimental station arrangement, and another 2500 rubles for the salary of the manager and his assistant (Aleksandrovskij, 1914, p. 182). The experimental station opening was largely due to the creation in 1910 at the Department of Land Improvements of the Department of Agriculture of the Special Staff in the number of 12 persons, who received a special training, first of all in Germany, for the introduction of the rational practices of an agricultural land and swamps drainage development (Tjulenev, 1958, p 25). Together with V. I. Morozov, under the direction of O. F. Florov during the end of September - October 1911, M. O. Tyulenyev expeditiously explored different types of swamps in Minsk province (V Minskuju gubernskuju, 1912, p. 57). During the expedition, a site was chosen near the station of Pukhovychi in the estate of P. M. Mirkovych near Minsk. In addition, in November 1911 - January 1912 M. O. Tyulenyev selected the swamp soil samples, which he analyzed using the methods of P. S Kosovych, O. N. Sabanin and Kyeldahl, who became the first ones «both from the scientific point of view and practical purposes ...» studying the swamp formations, their origin, chemical and physical properties in the Russian Empire (Tjulenev, \& Frolov, 1912, p. 32). The results of these studies were included into M. O. Tyulenyev's first scientific publication and are used nowadays for monitoring the agri-environmental indicators in the Republic of Belarus. From January 1, 1912 he was a trainee of the Department of Agriculture of the Swamp Drainage Culture Courses for graduates of the special agricultural educational institutions in Ryha Polytechnic Institute. Professor Knirin was the head of the courses. Instead of 24 persons, allowed by the Department together with M. O. Tyulenyev, 29 persons attended the courses on Applied Botany (50 hours), Soil Science (24 hours), Geodesy (24 hours), Peat Utilization (24 hours), Chemical Analysis (10 hours), Bulb Plant Studying (24 hours), and Swamp Culture (140 hours). In addition, another 200 hours were allocated to the practical and laboratory classes. As one of the three best graduates, in the summer of 1912, M. O. Tyulenyev was sent to Sweden (Stockholm, Jönköping), Denmark (Copenhagen) and Germany (Berlin research station and the farms of North Prussia) to brush up the knowledge and «... to learn about the station activity in the sphere of the swamp culture and bulb plants studies ...» (AAS, f. 251, d. 567, c. 34, p. 14). In addition, the Department of Agriculture got also acquainted with the work of the exemplary swamp lands of the Baltic region and Finland, as well as some provinces of Russia.

With the permission of the Head of Land Management and Agriculture on the report of the Agriculture Department of September 6, 1912 under No. 2395, from October 1 M. O. Tyulenyev, 1912 - a junior specialist in the agricultural part of the Department of Agriculture to perform the duties of «... the head of Section III, the Department of Agriculture...» 
(CSASPAU, f. 27, d. 17, c. 4155, p. 1), as well as until October 15, 1915 - a lecturer on the swamp culture and bulb plants cultivation at the St. Petersburg Agricultural Museum and an assistant editor of the «Zemlerob» magazine. The transition to a public service allowed M. O. Tyulenyev to receive the promotion to the 9th grade of the Petrovskyi rank plate, namely - a titular adviser. His first personal publication, «A Few Words about Swamp Culture in the Baltic Region,» was published symbolically in the «Swamp Science. Bulletin of Crops, Swamps Culture and Bulb Plants Studies» No. 1, 1913. Since 1912 the Bulletin began to be published by Minsk Swamp Station, edited by O. F. Flerov. The article was written on the basis of a survey trip to Estland, Lifland, Kurland provinces (Tjulenev, 1913, p. 97).

Among the reasons that made it impossible to carry out the complete drainage in the country, in the first place M. O. Tyulenyev considered the location of the land, in which private land tenure was wedged into the state one (Tjulenev, 1958, p. 25). This made it extremely difficult to carry out the whole cycle of work, since the private owners did not always consent to the drainage. As an important reason, the scientist pointed at the lack of the necessary machines and tools for cultivating the marshy soils for crops cultivation. He named the third most important reason - a poor quality level of drainage, because it was carried out not on the whole swamp, taking into account hydrological, hydrotechnical, soil-climatic and other conditions, but on the separate isolated areas. Another reason was the introduction of a foreign experience, which, first of all, aimed at the agricultural use of the dehydrated areas exclusively under meadows. M. O. Tyulenyev became a generating leader of the idea of creating domestic research institutions for the swamp development, which included the definition, in terms of individual natural-climatic and soil conditions of the country, of the norms and the degree of drying, the need for fertilizers, the study of the soil cultivation methods and crop care, stock crops, selection of crops, etc. His own conclusions for this issue are published in a series of the articles in the magazines «Zemlerobstvo» and «The Agricultural Bulletin» and even under kryptonimum. Their generalization is reflected in the collective work «Review Practice on the Fodder Plants. 1908 - 1913», published in St. Petersburg on behalf of the Department of Agriculture of the State Agricultural University in 1914 (238 p., 36 drawings, 6 cartograms and diagrams and 2 plans). The Review discloses the whole history of the formation and development of the national drainage culture of swamps, including the case study for its needs. At the beginning of $1911 \mathrm{M}$. O. Tyulenyev was involved in this process. Beginning with September 1, 1912, M. O. Tyulenyev was approved in the rank of a scientist agronomist and in the rank of the VIIIth class of Peter's I rank plate, - a college secretary with seniority, according to the submission of the chief of the IIId section of the Department of Agriculture on December 9, 1913 (CSASPAU, f. 27, d. 17, c. 4155, p. 1). He made some attempts to cure of the disease with another exacerbation of it in 1914. For this purpose he went to Sukhumi. Staying there, he published the article «Potato Storage» in the supplement to the journal «The Black Sea Agriculture», which was published under the auspices of Sukhumi Society of Agriculture. This fact was revealed for the first time, as it is not mentioned in one of the lifetime «Lists of Works» by M. O. Tyulenyev. At the end of 1915 he became a senior specialist in the agricultural part of the Department of Agriculture and a head of the training courses on the swamp culture and bulb plants studies in Kazan, for which he received «... 1800 rubles a year ...» (CSASPAU, f. 27, d. 17, c. 4155, p. 1). During World War I he was involved into the feed supply for the active army (CSASPAU, f. 27, d. 17, c. 4155, p. 18). During the years 1915 - 1917, he was a swamp culture specialist of the Volodymyr-Ryazan Department of Agriculture and State Property of Volodymyrskyi Region Departments. For the next two 
years, he became a senior specialist in the swamp culture of the Department of Agriculture of Volodymyrska province (nowadays - the Russian Federation). The period of $1915-1917$ of M. O. Tyulenyev's creative work was the least investigated. The additional historical researches are needed. During 1919 - 1921 he was a senior expert in the swamps culture of Kyiv Provincial Land Department and the assistant director of the «Peat Society» (Proskuriv). With the arrival of the Soviet power in Kyiv, in February 1919, he returned to his homeland. He dealt with the issues of peat harvesting. According to the statement, dated June 10, 1921, he was credited to the headquarters of «Ukrtorf» (CSASPAU, f. 213, d. 2, c. 717, p. 2). In Kyiv he worked as a senior inspector for the technical part of the inspection and audit department and was responsible for the activities controlling of the peat-harvesting organizations of the Left Bank Ukraine (Poltava, Kharkiv and Kremenchuk provinces) (CSASPAU, f. 27 , d. 17 , c. 4155 , p. 18). Thus, he was entitled not only to check, but also to fire, to appoint, to control in order to avoid abusing in the work of his employees. It was no coincidence that in accordance with «The Mandate», he was allowed to use all the means of transport and communications free of charge and even to have weapons. Unfortunately, the «Reports» on such business trips during the second half of 1921 - early 1922 were not preserved. But on his recommendation in the «Official Note», dated 4.10.1921, for example, Yurovsky, a vice-director of Lohvytska peat development department, was appointed the Head of Poltava Hubzemtorf instead of Golman (CSASPAU, f. 213, d. 2, c. 717, p. 19). There is information that beginning with 1.01.1921 till November 1922, M. O. Tyulenyev was also an employee of the section of the forage area (he made the reports at its meetings), and then he became a freelance employee of the reclamation section of the Agricultural Scientific Committee of Ukraine (Institute of Archival Studies of the NLUV, f. 176, d. 1, c. 11, p. 71). He acted as one of the main participants in the emergence of the Central Research and Reclamation Station in Kazarovychi in 1922. He joined the group to elaborate its "Charter» and the work program as a member of the Station Council. Through the Review Committee of the section for education and popularization of AGSCU under the kryptonimum - «T», he printed the abstracts for the edition for the relevant section of its official printed body - «The Bulletin of Agricultural Sciences». In every possible way, he supported the idea of creating the Research Institute of Water Management of Ukraine (nowadays - Institute of Hydromechanics of the NAS of Ukraine), headed by Professor Ye. Opakov, that he started his work in accordance with the decision of the reclamation section of the AGSCU of 19.10.1923, item 4 of the order №681 / 383 of 8.05.1922 by the People’s Commissar of the USSR from 3.05.1922, in accordance with the recommendation of the vice-head peat department (CSASPAU, f. 27, d. 17 , c. 4155 , p. 6), he was appointed, according to some information, the head of the scientific and technical department, and according to the others - the head of the pilot-reclamation part of Ukrmeliozem. From January 29, 1923, he was already a senior specialist in the field of amelioration of the same department and was responsible for the overall management of the amalgamation activities and the stations control of the Ukrainian SSR (CSASPAU, f. 331, d. 2, c. 37, p. 71). He personally founded the Sahaidach Irrigation Research Station (Kovalenko, 2005, p. 150). Also, by Decree No. 1 (85) of the main agrarian department from April 26, 1923, he became, until 1932, the director of the Scientific and Research Committee of Ukraine Rudnya-Radovelska Marsh and Reclamation Research Station, created on April 1, 1923.

Under the guidance and a direct participation of M. O. Tyulenyev the in-depth studies were conducted in Korosten district on an area of 655 hectares of a transitional-type grass bog with a peat depth of from 0 to $7 \mathrm{~m}$, with the study of the hydrographic side of the 
station's territory and the surrounding area. In addition, the work was done to lay a number of open and closed drainage systems and water wells. The work programmes were developed for seven multifactorial research schemes. The scientist initiated publishing and since 1926 became the author and editor of seven issues of «The Works» of the station. Already next year, his original work entitled «What to Do in the Swamp and how to Use it Best», was published on the basis of the research data from Rudnya-Radovelska Swamp Experimental Station. With reference to the experience of organizing a scientific support for the drainage of many Western European countries in the use of peat swamp after surface and radical improvement, he suggested using an appropriate practical set of measures. This approach was considered by the researcher as the only promising measure for the further development, first of all, of the Ukrainian Polissya. He justified the system of the agrotechnical measures after the drying: the soil tillage, the fertilizers, the terms and sowing rates, the crop sorts, the crop rotations, the stock, care, etc.; he calculated the economic efficiency and profits as well.

The scientist initiated and headed the organizing committee of the First All-Union Congress on Swamp Culture on September 24-26, 1927 at the Rudnya-Radovel Swamp Research Station. Together with D. O. Giovanni he represented the USSR at the Congress, held on October 15-18, 1927 in Minsk. He represented the experimental station and he was among the speakers at the First All-Union Meeting of Meadow-Researchers at Professor V. R. Williams State Meadow Institute., held February on 23 - March 1, 1928. At the morning meeting on February 26, 1928, M. O. TyulenHev reported on the results of a five year activity of the Rudnya-Radovel swamp station

Under these conditions, Rudnya-Radovel swamp experimental station in the second half of the 19200-ies actually became the main one for the study of the domain problems in the Ukrainian SSR because of its branches: a) Burovske Experimental Farm on the «Zamhlai» Swamp (Chernihiv region) since 1926, opened by Chernihiv District Land Department on an area of 437 hectares; b) Ozerianska station on the mossy marsh massif of Korosten region. M. O. Tyulenev also researched the region as a local historian, being a member of the Local Government Board during 1928 - 1932 (AAS, f. 251, d. 567, c. 34, p. 4). He has also worked in other public positions to polarize the latest natural sciences.

Since 1923, M. O. Tyulenyev was a part-time lecturer, conducting lectures on Swamp Culture and Bulb Plants Studies at Kyiv Agricultural Institute (nowadays - National University of Bioresources and Environmental Management of Ukraine). From 1.01.1930 till 1.11.1948 he was a diploma projects consultant in the sphere of the amelioration measures at Kyiv Hydromelioration Institute. During 1930 - 1934 - a full member of the Supreme Scientific and Technical Council of the NCLS of the USSR for consideration of land reclamation projects for drainage and irrigation of drained swamps (AAS, f. 251, d. 567, c. 34 A, p. 17). From 1934 till June 1941 - a member of the Committee of the NCL of the USSR on the invention and the scientific technical council of the Main State Committee for the NCR of the Ukrainian SSR. He was a member of the Scientific Councils at the UkrNRIHyM and the All-Union Research Institute of Swamps since 1932, and since 1940 a member of Kyiv Hydro-amelioration Institute (AAS, f. 251, d. 567, c. 34, p. 17). From 1932 till August 1941- a senior researcher, a head of the agro-irrigation and drainage sector and a scientific supervisor of the swamp research network at the Ukrainian Agricultural Research Institute (nowadays - the Institute of Water Problems and Reclamation of the NAAS). After the decision of the People's Commissar of the USSR on April 15, 1932 on the organization of Sulskyi Swamp Experimental Field (Romny district, Sumy region) and the material 
technical base replacement of the liquidated Rudnya-Radovelska experimental station on March 1, 1932, during 1932 - 1934 M. O. Tyulenyev was engaged in the deployment of Sulskyi Swamp Experimental Field activities. In 1935, together with M. N. Shevchenko and A. M. Yangel, he initiated moving of Pidstavska Swamp Research Station from Zolotonskyi District, Poltava region to Yahotynskyi district of Kiev region. Pidstavska Swamp Research Station was created at the beginning of 1916. The main citcumstances for this moving to a new location are considered by M. O. Tyulenyev to be the unsuccessful approach to the drainage process introduction by the first director P. V. Spesivtsev, who made it by means of the collapse and pumping of water by a centrifugal pump outside the shaft. According to the People's Commissar of the USSR order No. 35 of 1936, M. O. Tyulenyev became the scientific supervisor of the whole range of studies of Panfylo-Yahotynska central swamp station of the Ukrainia Research Institute of theagricultural land reclamation (nowadays Panfylska research station of the Institute of Agriculture of NAAS).

On July 4-8, 1938 M. O. Tyulenyev's report on «Drainage and Development of Swamps in the Ukrainian SSR» at the VIIth Plenum of the section of reclamation and hydrotechnics VASHNIL, actually, summed up the work of Ukrainian scientists in the drainage reclamation sphere of the pre-war period under the methodical coordinating start of the UkrNII of hydrotechnics and reclamation and the place of performance at Panfylska experimental station. For the complex implementation of the latest developments, he suggested reorganizing the Panfylo-Yahotynska swamp experimental station into Supiyska Zonal Swamp Research Station. Unfortunately, prepared by M. O. M. Tyulenyev, a number of original popular science publications on the swamps culture during this period, remained unpublished. From 1939 until the beginning of the German-Soviet War, he was a member of the expert-technical bureau of the NKZ of the UkrSSR for the consideration of the reclamation and hydrotechnical construction projects (AAS, f. 251, d. 567, c. 34, p. 17). The Resolution of the VASHNIL Qualification Commission of March 19, 1936 approved him a full member of the Ukrainian NR Institute of Hydrotechnics and Reclamation. In 1940 he graduated from Kyiv MarksLenin University (AAS, f. 251, d. 567, c. 34, p. 64).

At the session of the Specialized Academic Council at Moscow V. R. Williams Hydromelioration Institute he upheld the dissertation for the Doctor's Degree of Agricultural Sciences on the theme: "Growing Sugar Beet on the Dried Peat Soils of the UkrSSR» on September 21, 1940 (AAS, f. 251, d. 567, c. 34, p. 69). The correspondent diploma of VAK of the USSR under No. 000160 issued only on 11.03.1946 (AURIHM, f. 5144, d. 2, c. 102, p. 33). Not by chance, before the German-Soviet War of 1941M. O. Tyulenyev became a recognized classic of the land reclamation research in the country.

As the front approached Kyiv, he moved to the village of Panfyly. During the occupation of Yahotyn region, as the head of the drainage sector of Kyiv Hydromel. Institute, he conducted the research on the study of the agricultural technology of meadow grasses and fodder, vegetable and non-food crops (Tjulenjev, p. 2). In January 1942, after the restoration of the activities of Kyiv Soil Reclamation Institute, from March 1, 1942, he conducted lectures for the fourth- and fifth-year students at Hydroelectric, Peat-Mechanical and Soil Reclamation Faculties. During the occupation the work of M. O. Tyulenyev allowed to retain all property of the UNIIHyM dehumidification sector in Kyiv and all valuable equipment of the Panfyl swamp agrochemical laboratory (AAS, f. 251, d. 567, c. 34, p. 18). After the liberation of Kyiv from the German invaders in 1943, M. O. Tyulenyev was also the head of the department of agriculture until 1947. During 1944 - 1947 he headed the drainage department of the Agricultural Research 
Institute of Agriculture of Ukraine. After the announcement of the competition of the Academy of Sciences of the USSR for the election of its new members and correspondent members in 1948, the Scientific Academic Council of UNIIHyM nominated the candidates as corresponding members of the Academy of Sciences of the UkrSSR in the specialty «Agricultural Land Reclamation», at the meeting on May 14, 1948, based on the report of A. M. Yanholya, the Deputy Director for Scientific Work. Those candidates were: a director of the Institution, Candidate of Agricultural Sciences - S. M. Alpatiev and Doctor of Agricultural Sciences M. O. Tyulenyev (AAS, f. 251, d. 567, c. 34, p. 70). The members of scientific and technical meeting of Sulsky Swamp Research Field supported the nomination of the Presidium of the UkrSSR Academy of Sciences and by its letter No. 278 / m dated May 27, 1948. The letter was signed by Bovkun - the Chairman and Opryshko - the Secretary, on the report of the Deputy Director for Scientific Affairs V. S. Maksymenko. Already 5.06.1948 M. O. Tyulenyev agreed to be included into the list for the running compaign, writing the statement to the President of the UkrSSR Academy of Sciences (AAS, f. 251, d. 567, c. 34, p. 73). At the General Meeting of the UkrSSR Academy of Sciences on July 2, 1948, after the secret ballot, the head of the counting commission, Academician S. O. Lebedyev announced the result of the counting commission on the elections secret ballot of the corresponding members of the Academy of Sciences of the UkrSSR. According to the results of voting, M. O. Tyulenyev was unanimously elected a corresponding member of the Academy of Sciences of the Ukrainian SSR in the field of «Agricultural Sciences» (Palij, \& Khramov, 1998, p. 189).

On January 1, 1949, at the invitation of Academician O. I. Dushechkin, M. O. Tyulenyev started working as a senior researcher and the head of the agricultural land reclamation group at the Institute of Plant Physiology and Agrochemistry of the Academy of Sciences of the UkrSSR. He worked there until 1955.

At the same time, he remained working part-time as a senior researcher at UNIIHiIM (AAS, f. 251, d. 567, c. 34, p. 77). From April 8, 1949, in accordance with the decision of the Presidium of the Academy of Sciences of the UkrSSR (Protocol No. 11, § 13), he became a member of the Scientific Academic Council of the Institute of Plant Physiology and Agrochemistry of the Academy of Sciences of the Ukrainian SSR. According to another decision on January 7, 1949 (Protocol No. 1), he became a member of the Bureau of the Agricultural Sciences Department of the Academy of Sciences of the UkrSSR, which began its work in accordance with the decision of the RNC of the UkrSSR and the Central Committee of the $\mathrm{CP}(\mathrm{b}) \mathrm{U}$ «On the Organization of the Agricultural Sciences Department in the Structure of the Academy of Sciences of the UkrSSR» of October 20, 1945 (October 20, 1945) (CSASPAU, f. P-2, d. 7, c. 2148, p. 4-5). By the decision of the Presidium of the Academy of Sciences of the UkrSSR of January 26, 1951, he was elected a member of the editorial board of the Journal of Agricultural Sciences «The News of Agricultural Science» (CSAPA, f. 1, d. 71, c. 1, p. 68). At another meeting, which took place on March 9, 1951, M. O. Tyulenyev's work was praised for designing the meadow-drainage machine, the use of which on drainage soils helped to increase the harvest of various agricultural crops by $18-30 \%$ (CSAPA, f. 1, d. 71, c. 1, p. 149). To fulfill the decisions of the Presidium of the Academy of Sciences of the Ukrainian SSR of April 27, 1951 he headed the special complex expeditions in Snihuriv district, Mykolaiv region (1951) and Dymerskyi district, Kyiv region (1952-1956) to provide a scientific assistance to the collective farms of the Ukrainian SSR (Central State Archive of Public Associations, f. 1, d. 71, c. 2, pp. 1-7).

In 1952, according to the decision of the Presidium of the Academy of Sciences of the Ukrainian SSR, in addition to the membership in the Department of Agricultural Sciences 
Bureau, he became a member of the Council for the Study of Productive Forces of Ukraine. Each year, the number of various assignments, as well as the membership of the collegial bodies, continued to increase, which undoubtedly affected the efficiency of the fulfillment of the main duties. On July 29, 1952, the Presidium of the UkrSSR Academy of Sciences even adopted a special Decree No. 283, according to which, the corresponding member of the UkrSSR Academy of Sciences M. O. Tyulenyev was dismissed of his duties as the second deputy chairman and member of the Agricultural Sciences Department Bureau, the deputy chairman of the agricultural section for assisting major building structures of communism, from managing the issue of «Increasing the Productivity of Agricultural Plants in GrassGrowing Crop Rotation» and from the duties of a technical member of Ra propaganda of the Academy of Sciences of the UkrSSR and the authorized council of the scientific and technical propaganda at the Institutes of the Department of Agricultural Sciences (AAS, f. 251, d. 567, c. 34, p. 80).

He was among those members of the Agricultural Sciences Bureau of the Academy of Sciences of the UkrSSR, who at a meeting on July 10, 1954, supported the decision of the MAG of the Ukrainian SSR on the organization in its structure of the Ukrainian Academy of Agricultural Sciences with the mandatory transfer of the existing research institutions of the Academy of Sciences of the Ukrainian SSR to the newly created institution (CSAPA, f. 1, d. 71, c. 128, pp. 107-122). He continued working part-time at UNIIHyM under the permission of the Presidium of the UkrSSR Academy of Sciences of August 28, 1953, on the basis of the Resolution (Protocol No. 32, § 703). After the governmental decision on the ban of working at the same time in two research institutions, the Resolution of the Presidium of the Academy of Sciences of the UkrSSR of August 7, 1954 (Protocol No. 23-B, § 534 paragraph 2) he received a refusal to combine positions in the Institute of Physiology and Agrochemistry of the Ukrainian SSR and UNIHyM (AAS, f. 251, d. 567, c. 34 A, p. 83). But already on August 30, 1954, in view of the petition of the directors of the institutions of the UkrSSR and with the consent of the directors of the institutions of the UkrSSR Academy of Sciences, by the resolution of the Presidium of the UkrSSR Academy of Sciences (protocol No. 25-B, $\S 576$ ), he received the permission to combine positions in both institutes. This permission was signed by the Vice-President of the UkrSSR Academy of Sciences M. Semenenko (AAS, f. 251 , d. 567 , c. 34 A, p. 84).

Nowadays it is difficult to reproduce the situation objectively that arose when considering the problematic issues of the Institute of Plant Physiology and Agrochemistry of the Academy of Sciences of the UkrSSR on January 21, 1955, based on the results analysis of 1954, when the Vice-President of the Academy of Sciences of the Ukrainian SSR M. Semenenko stated that M. O. Tyulenev had paid little attention to the land reclamation laboratory, since he was employed in other institutions. The Vice-President of the Academy of Sciences of the Ukrainian SSR H. M. Savin added that it was a matter of managing the department at UNIIHyM. Under these circumstances, the next day M. O. Tyulenyev had to formally address a statement to the President of the Academy of Sciences of the UkrSSR - Academician O. V. Palladin. In the statement, he explained that the combination of positions was forced, because there was no experimental base at the Academy of Sciences of the UkrSSR in the swamps and wetlands, where the agricultural land reclamation laboratory, after four years of functioning, would have been able to conduct a relevant research. Therefore, a network of UNIIHyM specialized agencies was used for these purposes. At the same time he proved that he visited UNIIHiM no more than 3 days a week for 2-3 hours a day and his work consisted 
mainly in providing consultations on the certain agricultural development issues of swamps and a scientific guidance of the post-graduate students (AAS, f. 251, d. 567, c. 34, p. 85).

Under such circumstances, he was given support by the members of the Institute of Plant Physiology and Agrochemistry of the Academy of Sciences of the USSR. The members of the Institute considered him a great expert in marshland culture and bulb plants studies. In the document of October 20, 1955, its director, Academician P. A. Vlasyuk singled out the tremendous work, being done by M. O. Tyulenyev on the implementation of the achievements of the agricultural industry of science in the collective farms and state farms of the UkrSSR by means of the systematic speeches, made for the agricultural specialists and collective farmers, conducting lectures, making reports on the issues of the drainage and agricultural use of swamps and wetlands (AAS, f. 251, d. 567, c. 34, p. 67). There is no coincidence that on November 26, 1955, by the decision of the Higher Education Commission at the Ministry of Higher Education of the USSR, he was awarded the academic title of Professor in the specialty «Agricultural Land Reclamation» (AURIHM, f. 5144, d. 2, c. 102, p. 34).

From 1955 till 1956 he headed the laboratory of the animal feed production sector of the Presidium of the Academy of Sciences of the UkrSSR. In connection with the closure of the Department of Agricultural Sciences within the Academy of Sciences of the UkrSSR (the resolution of the Presidium of the Academy of Sciences of the UkrSSR of May 25, 1956, Protocol No. 29, § 370) together with seven academicians and 17 corresponding members of the UkrSSR, M. O. Tyulenyev became the member of the personnel of the Biological Sciences Department. After the publication of the orders of the MAG of the UkrSSR № 535 dated 13.08.1956 and № 216 dated 20.08.1956 on UkrNIIHyM on the organization of the department of development of the drained flood lands (AURIHM, f. 5144, d. 2, c. 102, p. 35), from August 13, 1956, he returned again to work at the UkrNII of hydrotechnics and land reclamation as the head of the development department of floodplain lands, which he managed until April 21, 1961. In addition, he worked as a Professor at the Department of Agricultural Land Reclamation and Fodder Production of the Ukrainian Academy of Agricultural Sciences. According to the submission of the Scientific and Technical Society of Agriculture and Forestry, the Ministry of Agriculture of the UkrSSR nominated M. O. Tyulenyev, the corresponding member of the UkrSSR Academy of Sciences, in the additional list of candidates for election as full members of VASHNIL in 1956 (CSAPA, f. 27 , d. 18 , c. 8806, p. 85 ). However, it did not happen.

On the occasion of the 40th anniversary of the Great October Socialist Revolution, he prepared a fundamental contextual article «Bulletin of Scientific and Technical Information» that can be viewed as a historical essay on the establishment and development of a scientific support for the drainage land reclamation in Ukrainian lands to the UNIIHyM. During 1958 on the implementation of the order № 879 of the Ministry of Agriculture of the UkrSSR of November 23, 1957 and the decision of the Presidium of UAAS № 411 of December 22, 1957, M. O. Tyulenyev, together with other leading scientists of the UkrSSR Academy of Sciences and UAAS, was a participant and gave a presentation at the seminars-meetings on the topic «Assistance of Collective farms and State Farms in the Development and Implementation of a Proper Agricultural Management System». Such meetings were held in Kyiv, Kharkiv, Dnipropetrovsk, Odessa, Lviv, and were attended by 465 people from 157 research institutions and agricultural establishments (Brovenko, \& Kalinin, 1958, p. 82). During the exchange of views, the three most important steps were identified in the work on the development and implementation in production of the correct system of households 
economy. The first stage was the development of measures by the scientific institutions and sectoral agencies to increase the production per 100 hectares of agricultural land at the lowest cost of labour and resources in the major natural and climatic zones of the UkrSSR with the appropriate recommendations issuance. At the second stage, to conduct the soil surveys and to draw up soil maps for each collective farm and state farm for 1961. At the third stage, the development and implementation of a scientifically sound management system, based on the latest knowledge and the best practices to be carried out. To fulfill the above-mentioned items on the swamp culture, M. O. Tyulenyev worked for the rest of his creative life. In 16 regions of the UkrSSR it was planned to drain and cultivate 600 thousand hectares of crops. The Central Committee of the Communist Party of Ukraine, the Council of Ministers of the UkrSSR approved the elaborated plans and gave consent to the Hydropower Industry to implement these measures by the method of the people labour force. This approach was confirmed by January plenums of the Central Committee of the CPSU and the Central Committee of the Communist Party of Ukraine in 1961.

Due to the deterioration of his health, the resolution of the UAAS Presidium (Protocol $10, \S 89)$ of 21.04.1961 transferred him to the position of a senior researcher at UNIIHyR (AURIHM, f. 5144, d. 2, p. 102, p. 36) (AURIHM, f. 5144, d. 2, c. 102, p. 36). After the decision of the Presidium of the UkrSSR Academy of Sciences of July 20, 1962 (Protocol No.33, §399), on the renewal within the Academy of Sciences of the UkrSSR of the Department of Agricultural Sciences, in accordance with the decision of October 26, 1962 (Protocol No. 46, § 535), he became a member again (AAS, f. 251, d. 567, c. 34, p. 93). But not for a long period of time. Next year the previous decision was cancelled. After the retirement in April 1963, from August 22, 1964, on the order of UkrNIIHyR D No. 299, he worked as a scientific consultant of the department of development of flood lands of UkrNII of hydrotechnics and land reclamation (AURIHM, f. 5144, d. 2, c. 102, p. 37). The corresponding submission to the name of the director of the institute S M. Alpatiev was made by a new head of the department Kh. M. Starikov. According to M. O. Tyulenyev's statement from April 8, 1963 to the department of the scientific personnel of the Academy of Sciences of the UkrSSR he transferred his official address to the Institute of Plant Physiology of the Academy of Sciences of the UkrSSR with the explanation that he it dealt with the photosynthesis of plants related to the department of biological sciences of the Academy of Sciences of the UkrSSR (AAS, f. 251, d. 567, c. 34, p. 94). After the May 1966 Plenum of the Central Committee of the CPSU in the country began the work on a large-scale land reclamation. Under such circumstances, both theoretical and practical M. O. Tyulenyev's achievements, in terms of experience, were in demand, perhaps, for the first time in the country. Despite the huge demand, the health problems prevented him from continuing the scientific research. According to the submission of Kh. M. Starikov, from May 7, 1969, the Order of No. 149 on UkrNIIHyR, dated May 12,1969, «... his own will and in connection with a poor health ...», dated May 3, 1969, M. O. Tyulenyev got dismissed from work (AURIHM, f. 5144, d. 2, c. 102, p. 67).

He died on December 3, 1969. He was buried in Baikove cemetery in Kyiv. By Order No. 1435 of December 17, 1969 at the Presidium of the Academy of Sciences of the UkrSSR, signed by Academician V. S. Hutyri he was expelled from the corresponding members of the Academy of Sciences of the UkrSSR (AAS, f. 251, d. 567, c. 34, p. 98). The creative heritage of this eminent researcher, often referred to in the professional environment as the «Ukrainian Weber», is 218 scientific papers, published during the period of $1911-1964$. Some of his scientifically substantiated ideas for agricultural use of the peat-marsh fund of 
Ukraine, unfortunately, have not been published and are kept in the form of the manuscripts at the Institute of Archival Studies of the NLU NASU.

The Conclusions. Summing up, to understand what M. O. Tyulenev did, one should return again to his prognostic fundamental researches concerning, first of all, the use of the drained lands of the humid zone of Ukraine, and especially of Polissya. As early as 1954, in his fundamental article, «The Development of Polissya lowland is a Matter of Great National Economic Importance,» he outlined six basic elements that allow a rational use of sod-podzolic soils of the region. It was primarily about measures to regulate the water regime, namely: 1. A proper crop rotation, sown on all elements of the relief (floodplains, slopes and watersheds); 2 . The afforestation of sands and forest plantations in low-forested watersheds; 3. Creating ponds and reservoirs, as well as large reservoirs in river floodplains; 4. The regulation of rivers - water intakes for drainage systems; 5 . The formation of drainage channels and necessary water regulating structures on them for drainage systems; 6 . The agromeliorative measures to regulate the water-air regime directly on the drained lands. According to the scientist, their full and systematic introduction on the background of fertilizer soils, primarily organic, will preserve the potential fertility of sod-podzolic soils and prevent them from becoming poor sandy. Thus, the growth and development of livestock for the needs of the region could have occurred. M. O. Tyulenyev's scientific researches remain a road map for posterity to this day.

Acknowledgments. I am sincerely thankful to the First Deputy of the State Archival Service of Ukraine Kisil Ivan Mykolayovych for his assistance in finding the documents for the scientific research.

Funding. The author received no financial support for the research, authorship, and/or publication of this article.

\section{BIBLIOGRAPHY}

Aleksandrovskij, N. A., Dmitriev, A. M., Gluhov, M. M., Rozen, G. V., Tjulenev, N. A., \& Shirokih, I. P. et al. (1914). Obzor meroprijatij po kul'ture kormovyh rastenij. 1908 - 1913 (pod obshh. red. V. N. Shtejna) [Feed Crop Activities Review. 1908 - 1913 (under the general editorship of V. N. Stein)]. S.-Peterburg, 182 p. [in Russian]

Arkhiv Akademiji nauk URSR [AAS - Archive of the Academy of Sciences of the USSR].

Arkhiv Ukrajinsjkogho naukovo-doslidnogho instytutu ghidrotekhniky i melioraciji [AURIHM Archive of the Ukrainian Research Institute of Hydrotechnics and Melioration].

Bachkala, O. V. (2006). Dijaljnistj profesora M. O. Tjulenjeva v rozvytku siljsjkoghospodarsjkoji osushuvaljnoji melioraciji na torfovo-bolotnykh gruntakh [The Activity of Professor M. O. Tyulenyev in the Development of Agricultural Drainage Land Reclamation on Peat Swamp Soils]. Istorija nauky $i$ bioghrafistyka, 1. URL: http: // ind.dnsgb.com.ua/2006-1/06bovtbg.html. [in Ukrainian]

Brovenko, F. M., \& Kalinin, Gh. A. (1958). Naukovo-obgruntovanu systemu vedennja ghospodarstva - kozhnomu kolghospovi i radghospovi [Scientifically grounded system of economy management - each collective farm and state farm]. Visnyk siljsjkoghospodarsjkoji nauky, 10, 82. [in Ukrainian]

Centraljnyj derzhavnyj arkhiv ghromadsjkykh ob’jednanj Ukrajiny [CSAPAU - Central State Archive of Public Associations of Ukraine].

Centraljnyj derzhavnyj arkhiv vyshhykh orghaniv vlady ta upravlinnja Ukrajiny. [CSAHAGUCentral State Archives of Higher Authorities and Governance of Ukraine].

Derzhavnyj arkhiv m. Kyjiv [SAK - State Archives of Kyiv].

Dovghoruk, Ju. O. (2018). Jaghotynsjkyj period zhyttja ta roboty vydatnogho vchenogho vitchyznjanoji aghrarnoji nauky profesora M.O. Tjulenjeva [Yahotyn period of life and work of the prominent scientist of domestic agrarian science of Professor M. O. Tyulenyev]. Jaghotynsjki visti, 26 lystopada, 93, 276, 5. [in Ukrainian] 
Gimbarzhevs `ky`j, V. R., \& Kalanty`renko I. I. (2003). Tyulenyev My`kola Oleksandrovy`ch (1889-1969) [Mykola A. Tyulenyev (1889-1969)]. Vcheni-g 'runtoznavci, agroximiky', zemleroby' (pp. 316-318). Ky'yiv: Agrar. nauka. [in Ukrainian]

Instytut arkhivoznavstva Nacionaljnoji biblioteky V. I. Vernadsjkogho [ASI NLU-Archive Studies Institute of V. I. Vernadskyi National Library in Ukrainian].

Kalanty`renko, I. I. (1984). Tyulenyev My`kola Oleksandrovy`ch [Mykola A. Tyulenyev]. Ukrayins 'ka Radyans 'ka Ency klopediya [The Ukrainian Soviet Encyclopedia]. Kyiv: URE, 11, 1, 41. [in Ukrainian]

Kovalenko, P. I. (ed.). (2005). Tjulenjev Mykola Oleksandrovych [Mykola A. Tyulenyev]. Instytut ghidrotekhniky i melioraciji. Zasnuvannja, rozvytok ta najvazhlyvishi naukovi dosjaghnennja za 75 rokiv [Institute of Hydrotechnics and Reclamation. Foundation, development and major scientific achievements during 75 years]. Kyiv, 170 p. [in Ukrainian]

Palij, V. M., \& Khramov, Ju. O. (Comps.) (2018). Nacionalina akademija nauk Ukrajiny: Personaljnyj sklad. 1918 - 2018 [National Academy of Sciences of Ukraine: Staff. 1918 - 2018]. 7-e vyd., dop. j vypravl. Kyiv: Feniks, 560 p. [in Ukrainian]

Postanova Verkhovnoji Rady Ukrajiny. (2019) Postanova Verkhovnoji Rady Ukrajiny «Pro vidznachennja pam'jatnykh dat i juvilejiv u 2019 roci vid 18.12.2018 roku», N 2654-VIII [Resolution of the Verkhovna Rada of Ukraine «On commemoration of dates and anniversaries in 2019 of 18.12.2018», No. 2654-VIII]. Holos Ukrajiny, 1 (7007), 4. [in Ukrainian]

Shtakal, M. I., Virjovka, V. M., Tkachov, O. I., \& Shtakal, V. M. (2015). Do 100-richchja osushennja i osvojennja zaplavnykh zemelj Lisostepu [To the 100th anniversary of the drainage and development of the floodplain lands of the Forest-Steppe]. Zbirnyk naukovych prac NNC «Instytut zemlerobstva $N A A N », 2$, 174. [in Ukrainian]

Tjulenev, N. A. (1913). Neskol'ko slov o kul'ture bolot v Pribaltijskom krae. Bolotovedenie [A few words about swamp culture in the Baltic region. SwampMarsh science]. Vestnik kul'tury i izuchenija bolot i lugovodstva, 1, 97-100. [in Russian]

Tjulenev, N. A. (1958). Itogi i sovremennoe sostojanie voprosa o sel'skohozjajstvennom ispol'zovanii osushennyh torfjanyh pochv [Outcome and current state of the agricultural use of dried peat soils]. Bjulleten' nauchno-tehnicheskoj informacii, 4, 24-31. [in Russian]

Tjulenev, N. A., \& Frolov, A. G. (1912). Nekotorye dannye o bolotnyh pochvah Minskoj gubernii [Some data on the swamp soils of e Minsk province]. Bolotovedenie: vestnik Minskoj bolotnoj lpytnoj stancii, 31, 32. [in Russian]

Tjulenjev, M. O. (1942). Vykorystannja bolit jak siljsjkoghospodarsjkykh ughidj [Use of Swamps as Farmland]. Ridna nyva, 27 (13 serp.), 2. [in Ukrainian]

V Minskuju gubernskuju. (1912). V Minskuju gubernskuju zemskuju upravu: doklad po voprosu ob ustrojstve bolotnogo opytnogo hozjajstva pri Bolotnoj opytnoj stancii Minskogo gubernskogo zemstva [To Minsk Provincial Administration: report on the structure of the wetland pilot farm at Swamp Provincial Station of Minsk Provincial Zemstvo]. Doklady s prilozhenijami po Pervomu ocherednomu Minskomu Gubernskomu Zemskomu Sobraniju. Po sel'skohozjajstvennym voprosam [Reports with annexes on the First regular Minsk Provincial Zemsky Assembly. On agricultural issues]. (p. 57). Janvar'. Minsk. [in Ukrainian]

Verghunov, V. A. (2016). Kuljtura bolit na Poltavshhyni: stanovlennja ta rozvytok u svitli tvorchoji spadshhyny P.V. Spesyvceva [Swamp Culture in Poltava Region: Formation and Development in the Light of P. V. Spesivtsev's Creative Work Heritage]. Poltava: TOV «Kopi-centr», 160 p. [in Ukrainian]

Voron, V. P. (2016). Obrazovatel'nyj i prosvetitel'skij aspekty v dejatel'nosti Minskoj bolotnoj stancii v $1912-1915$ gg. [Educational and Informational Aspects of the Activity of Minsk Swamp Station in 1912 - 1915]. Nauchnye trudy Respublikanskogo instituta vysshej shkoly, 16-1, 63-69. [in Russian]

The article was received on March 18, 2019. Article recommended for publishing 06/11/2019. 